\title{
Destination Brand Personality, Self-Congruity Theory and the Intention to Visit a Destination
}

\author{
Destinasyon Marka Kişiliği, Öz uyum Teorisi ve Destinasyonu Ziyaret Niyeti
}

\section{Edina AJANOVIC* Beykan ÇIZZEL ${ }^{* *}$}

\begin{abstract}
Although in branding strategies the concept of brand personality is very popular with the aim of differentiating between similar consumer goods on the market, the characteristics of this concept remain insufficiently explored and in particular, as applied to tourism destinations. Marketers and researchers should also perceive tourists as individuals (not only as segments or groups), each with his/her selfopinion and self-perception which can define and affect his/her future behaviour and actions. Introducing the concept of self-congruity theory and its match with destination brand personality can be useful in predicting tourist behaviour. In this paper the researcher applied different method to examine the perceived brand personality of an unknown destination and its relation to the self-concept and intention to visit that destination. The hypothesis that claims there is a relationship between destination brand personality, self-congruity and the tourists' intention to visit a certain destination was tested and supported after the analysis of the data obtained during the survey. The study results provide useful implications for destination marketers as to how should they evaluate and test destination branding and marketing efforts.
\end{abstract}

Keywords: Destination Brand Personality, Self-Congruity Theory, Intention to Visit a Destination, Video Promotion Material

Öz: Pazardaki tüketici ürünlerini farklılaştırmak amacı ile marka kişiliği markalama stratejilerinde oldukça popüler olmasına rağmen, bu kavram özellikleri turizm destinasyonları üzerinde yeterince araştırılmamıştır. Stratejilerin ve aktivitelerin planlaması yapılırken pazarlamacılar ve araştırmacılar çoğu zaman turistleri bir grup veya kesim olarak görmektedirler; fakat turistler kendilerine ait düşünceleri ve algıları olan bireyler olarak da görülmelidir. Çünkü bu öz-algı kavramı onların gelecekteki davranışı belirleyebilir. Bu nedenle öz-uyum teorisinin kavramlarını tanıtmak ve destinasyon kişiliği kavramıyla birleştirerek turist davranışı tahmin etmek mümkündür. Bu çalışmada, araştırmacılar bilinmeyen bir destinasyonun algılanan marka kişiliği, benlik kavramı ve bu destinasyonu ziyaret etme niyeti ile olan ilişkisini incelemek için farklı bir yöntem uygulamışlardır. Araştırmada katılımcılara bilinmeyen bir turist destinasyonun tanıtım videosu izletilmiş ve katılımcıların bu destinasyonu ziyaret etme niyeti ölçülmüştür. Araştırma sürecinde toplanan verilerin analizi ile destinasyon marka kişiliği, öz-uyum ve destinasyonu ziyaret etme niyeti arasında ilişkilere yönelik hipotezler test edilmiştir. Çalışma sonuçları turizm pazarlamacılarına, destinasyon markalama ve pazarlama faaliyetlerinin değerlendirilmesine yönelik faydalar sağlayacaktır.

Anahtar sözcükler: Destinasyon Marka Kişiliği, Öz-Uyum Teorisi, Destinasyonu Ziyaret Etme Niyeti, Görüntülü Tanıtım Araçları

\footnotetext{
* Öğr. Gör., Akdeniz University, Tourism Faculty, Antalya. edinaajanovic@akdeniz.edu.tr

** Prof. Dr., Akdeniz University, Tourism Faculty, Antalya. beykan@akdeniz.edu.tr
} 
One of the topics in brand literature that is gaining in popularity and significance in research is that of brand personality. The idea of particular brand having its own personality, which refers to "the set of human characteristics associated with the brand" (Aaker 1997, 347), has been occupying researchers for decades. One of the first papers on brand personality related to tourism destination was conducted by Ekinci and Hosany (2006) and it continued with an investigation into the relationship between destination brand personality and: (1) destination image (Hosany, Ekinci \& Uysal 2006; Tasci \& Kozak 2006), (2) between host image and tourist behaviour (Ekinci, Sirakaya-Turk \& Baloglu 2007) and (3) between self-congruity theory and tourist behavioural intentions (Usakli \& Baloglu 2011).

As we live in an era of overall consumer saturation, tourists are no longer looking only for destinations with golden sand beaches, blue seas, historical places, beautiful scenery, and friendly people as they can find these in the majority of touristic places. In this situation working on the differentiation of one touristic destination from any other provides a great challenge for travel marketers and DMO's. This is the reason why Ekinci and Hosany (2006) suggest that "destination personality can be used as a viable metaphor for building destination brands, understanding visitors' perception of destinations, and crafting a unique identity for tourism places". Applying the basic principle of self-congruity theory to tourism destinations, it was found by Sirgy and Su (2000) that "the greater the match between the destination personality and the visitor's self-concept, the more likely it is that the visitor will have a favourable attitude towards that destination". This was the starting point for the study of destination brand personality by Usakli and Baloglu (2011) who claimed that if we are able to understand the relationship between the destination personality and the self-concept of the visitor we might obtain more precise insights into tourist behaviour.

In the majority of studies concerning destination brand personality, research was conducted among tourists that have already visited one destination or they were asked to recall their last trips and the places visited. Participants were asked to define and recognize different items of the destination's personality and their intentions to recommend or to return to the referred destination were measured. In this study, by accepting the already published conceptual and empirical work on this topic, the relationship between the perceived brand personality of an unknown destination, two dimensions of self-congruity theory and the intention to visit that destination will be examined. For this, a short promotional video of a destination unknown to participants was used as a starting point in finding: (1) the relationship between brand personality traits and the participant's self-perception and (2) how this link will impact upon their potential tourist behaviour in respect to the intention to visit that destination. The research results are considered useful to destination marketers as they will be able to see effects of their video promotional activities in advance, before being published. This will allow them to make the necessary corrections to it so that it can reflect the desired image and personality of the destination.

\section{Literature Review}

Brand personality has a long history in the context of brand literature. Research was focussed upon how brand personality enables consumers to express themselves (Belk 1988; Malhotra 1988; Kleine, Kleine \& Kernan 1993), its importance in brand differentiation, driving customers' preferences and being a common denominator in the marketing of a brand across cultures (Aaker 1997). The largest incentive, the one that caused even more interest in brand personality research, was Aaker's (1997) development of a "brand personality scale" and defining the dimensions of the same. Aaker was one of the first trying to clearly distinguish 
brand personality from other brand constructs; in consequence she conducted research into consumer behaviour on brand personality. She developed the conceptual comprehension of the structure of brand personality and the psychological mechanism by which this construct operates. As a result of Aaker's study the five dimensions of brand personality were defined: sincerity, excitement, competence, sophistication and ruggedness through a reliable and general 42-item measurement scale.

According to Keller (1993), "brand personality tends to serve symbolic or self-expressive function” for consumers against 'product-related attributes' whose primary function is of a utilitarian nature. "Brand personality traits" differ from human ones in the way they are formed. According to Park (1996), we perceive human personality traits on the basis of the individual's behaviour, attitudes/beliefs, physical characteristics and demographic characteristics. On the other hand, perceptions of brand personality traits can be formed according to direct contact (associating people with the brand) or through indirect contact (attributes related to the product, associations with the product category, brand name, logo or symbol etc.) between the consumer and the brand (Aaker 1997).

When analysing the brand personality construct in the field of tourism research, the first paper that one should start with is by Hosany, Ekinci and Uysal (2006) regarding the connections between the destination personality of the tourism destination and the destination image. As there was no previous research on the application of brand personality to tourism, they decided to apply Aaker's (1997) BPS to places and tourism destinations. By adapting Aaker's definition of brand personality, they viewed the destination personality as "the set of human characteristics associated to a tourism destination" (Hosany, Ekinci \& Uysal 2006, 639). In addition to the use of BPS measures for brand personality, they also used measures of the affective and the cognitive components of the destination image drawn from previous research. Their results indicate that the destination image and the destination personality are related concepts, consistent with the conceptual approaches concerning this relation made by Plummer (1985). In line with their approaches, in Hosany's paper (Hosany et al. 2006) brand image was seen as a universal concept while brand personality was seen as its affective component.

In the literature, studies of the effects and relations between the destination personality and tourist behaviour might be found. Accordingly, in their study, Ekinci and Hosany (2006) found that one of the dimensions of the destination personality has a significant effect upon the tourists' intention to recommend certain destination. Ekinci et al. (2007) found that the destination personality has a positive influence upon both the intention to return and word of mouth. Usakli and Baloglu (2011) have also shown in their empirical study that the destination brand personality will have a positive influence on the intention to recommend and the intention to return. Following on from the finds from previous research, the first hypothesis in this study can be drawn:

\section{H1: The destination brand personality will have a direct positive influence on visiting intentions.}

Since Rosenberg's (1979) denotation of "self-concept" as the "totality of the individual's thoughts and feelings having reference to himself/herself as an object", many scholars seem to agree on this term (Sirgy 1982). In Sirgy's (1982) critical review of self-concept research, his research problem concerned the theoretical and methodological underpinnings of self-concepts studies. 
In his research, Levy (1959) claimed that in the identification process of goods in the marketplace, it is not functionality but the symbolic encounter that affects the consumers' behaviour. Following this proposition, different self-concepts models were derived in order to describe and explain consumer behaviour. According to the Sirgy's "self-image/ product-image congruity theory" (Sirgy 1982), "product cues involving images usually activate a self-schema that involves the same image". Sirgy claims that the value placed upon the product and its image attributes will be influenced by the evoked self-schema. Following this theory, perception of positive product-image and self-image will result in positive self-congruity which will lead to the approach to purchase motivation.

In his review of previous studies examining the relationship between actual selfconcept/product-image congruity and consumer behaviour Sirgy (1982) summarized that studies support the existence of a:

Relationship between actual self-image/product-image congruity, ideal self-image/product image congruity and consumer choice - product preference, purchase intention, and or product usage or loyalty.

Furthermore, Helgeson and Supphellen (2004) compared self-congruity and brand personality both conceptually and empirically in their research. The study revealed that the two concepts are empirically discriminate and that both brand personality and self-congruity have independent and positive effects upon brand attitudes. Therefore we can draw the second hypothesis:

\section{H2: Self-congruity will positively affect visiting intentions.}

Sirgy and Su (2000) found that two dimensions of self-congruity theory - actual and ideal congruity - will have a positive impact on tourist behaviour. Combining these finding with the above mentioned studies, the following two sub-hypothesis are presented:

H2a: Actual self-congruity will positively affect visiting intentions.

$H 2 b$ : Ideal self-congruity will positively affect visiting intentions.

As shown by the literature of self-congruity theory, "the greater the congruity between the human characteristics that consistently and distinctively describe an individual's actual or ideal self and those that describe a brand; the greater the preference of referred brand will be" (Sirgy 1982; Malhotra 1988).

According to self-congruity theory, there is compatibility between the destination personality and the visitors' self-perception. Aaker (1995) mentioned that "the basic notion of self-congruity theory refers to the drive for consumers to prefer brands with personalities congruent with their own personality". If we apply the basic principles of this theory to the context of tourism destinations, it can be assumed that the more the destination personality is compatible with visitor's own self-concept, the greater are the chances for this visitor to have a positive attitude in respect to the destination. It was empirically approved in the work of Usakli and Baloglu (2011) that self-congruity is a mediator in the relationship between the destination brand personality and the intention to recommend and return. From this, the third and final hypothesis can be presented:

H3: Self congruity will mediate the relationship between the perceived destination brand personality and visiting intentions.

The proposed model tested in this paper is outlined in Fig. 1. 


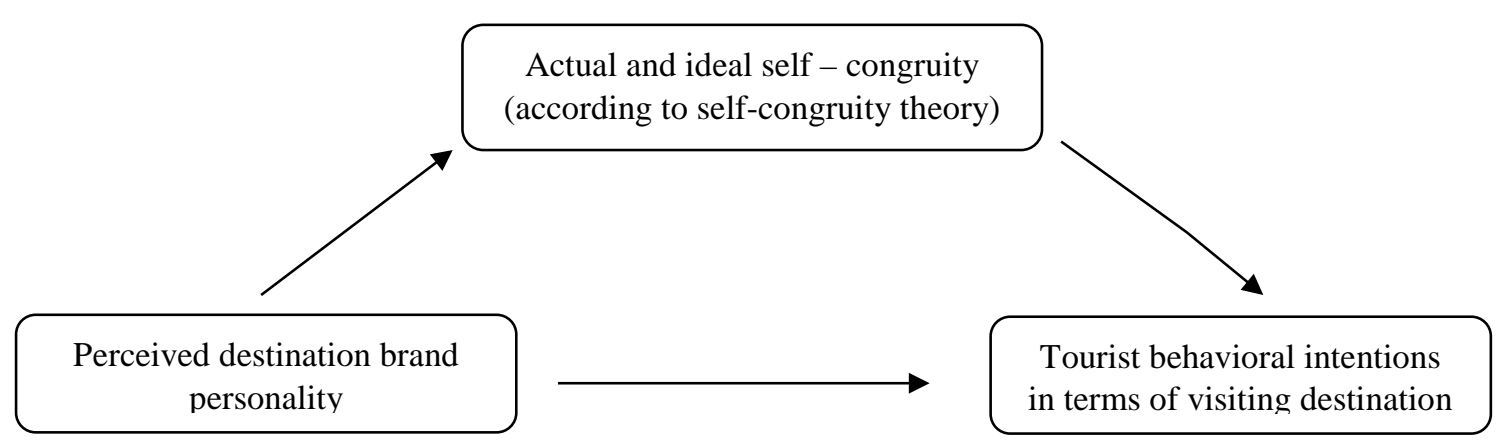

Fig. 1. Proposed model of hypothesis to be tested

\section{Methodology}

A survey research design was applied in this study. Based upon the literature review and by following the scale development procedure used in the previous studies (Usakli \& Baloğlu 2011) a questionnaire for the data collection process was developed. The whole process of defining an adequate method of research and questionnaire development will be explained in the continuation.

\section{Choice of Tourism Promotional Video}

The idea of using a tourism promotion video in this research was partially based on Nicoletta and Servidio's (2012) study in which they evaluated tourism photos as an important tool in promoting certain tourism destination and how it affected the decision making processing. The results of their study suggested that the positive perception of the tourism destination influences the personal motivation and decision-making process. Positive images result in a positive impression of destination in the mind of a visitor, affecting their future behaviour (Chen \& Tsai 2007).

Nicoletta and Servidio used photos as a promotional material with the goal of measuring affective and decision making process on the perceived destination image. By following Hosany's et al. (2006) statement that brand image is a more comprehensive concept, while brand personality represents the affective component of brand image, it was found appropriate to use a similar method to measure the destination brand personality. As tourism related videos consist of a large number of moving images, which in short period of time represent and promote different aspects of one tourist destination, this type of tourism promotion material was used in this research. Tourism destinations represent a mix of different features of one destination and it is hard to catch the whole concept relying solely upon images. Because of this, DMOs are also using videos in their marketing and promotion campaigns.

In order to find an appropriate video for this research, an extensive search for an adequate tourism promotion video that can be found on Internet was conducted. A large number of videoshared cites, official web pages of DMOs and other sources were checked in this search. A short 3-minute promotion video of Vancouver in Canada was found and defined as a starting point for the questionnaire that will be used in this research. The fact that this research will be conducted among Turkish students and it was assumed that Canada will be a less well known tourism destination for this group of participants. This was done so that "familiarity with the place does not affect the result of the research study" as noted in the literature (Yüksel \& Akgül 2007). In this video any information (regarding destination name, slogans, logos or symbols of 
destinations that can be easy recognized) was not shown; only music was played in the background. In creating this kind of video, an editing computer program was used to blur some parts of the video (where the Canada flag was shown) and to exclude the name and logo of Vancouver DMO at the end of the video. When the editing was finished, the video was named "Destination Z". Before showing the video, a short notice was written that stated that the name of the destination is not of great importance and the necessity to think about this destination in terms of personality traits was pointed out.

\section{Developing Brand Personality Scale}

Although Aaker's BPS is widely recognized and used in the branding literature, some of its items are not applicable to tourism destinations (Hosany et al. 2007). Therefore to extract the relevant items of the BPS scale the scale development procedure was conducted in two stages - free-elicitation to identify the unique traits of the destination and BPS's 42 item content validity testing (Usakli \& Baloglu 2011). However, in the personality trait generation phase, on the sample of 30 participants recruited using a convenience sampling technique, there was no personality trait that was out of the BPS scale and mentioned by at least $25 \%$ of the participants as in Usakli and Baloglu study. At the second stage in achieving content validity of the scale, the same number of participants decided which personality traits (from a total of 42) accurately describe the destination shown in the video. Again, different from Usakli and Baloglu's study where 23 items had mean rating of 3.00 and above (which was considered as a cutoff) in this study more than 35 traits showed mean ratings of more than 3.00. In order to find the valuable and most accurate number of traits describing this destination, the total mean score was taken as a cutoff at 3.74. As a result, a set of 26 personality traits was determined for the final study. These were split across five dimensions: sincerity (cheerful, friendly, original), competence (technical, intelligent, successful, confident,), excitement (cool, daring, imaginative, modern, exciting, spirited, young, up-to-date, independent, contemporary), sophistication (charming, upper-class, glamorous, good looking, smooth), rugged (wholesome, tough, Western, outdoorsy). After deriving a unique personality traits and testing content validity, a 5-point Likert-type scale was used for the measurement of the new established scale.

\section{Self-Congruity Measurements}

Sirgy et al. (1997) developed a method of measuring self-congruity (referred to as a direct score formula or global measurement approach) based on "tapping the psychological experience of self-congruity directly and globally". This method does not contain any predetermined attributes, thus it deals with the use of irrelevant attributes. Since the new method measures self-congruity holistically, it is applied in a tourism context (Sirgy \& Su 2000; Usakli \& Baloglu 2011). In its modified version, it will also be used in this paper. The respondents were asked to think about the destination in terms of personality traits and about how they see themselves. They were asked to evaluate the compatibility between the destination personality and their self-perception by indicating their levels of agreement with the following statements: for actual self-congruity: "Destination $Z$ is consistent with how I see myself", "My personality is similar to the personality of Destination Z" and "The personality of Destination $Z$ is congruent with how I see myself"; for ideal self-congruity: "Destination $Z$ is consistent with how I would like to see myself"; "I would like to be perceived as similar to the personality of Destination Z" and "The personality of Destination Z is congruent with how I would like to see myself'. Both actual and ideal self-congruity statements were derived from 
the previous research (Sirgy et al. 1997; Sirgy \& Su 2000; Helgeson \& Suphellen 2004; Usakli \& Baloglu 2011) and were measured on the 5-point Likert scale.

Tourist behavioural intention in terms of intention to visit and overall brand personality of destination presented in the video, was measured by using 10 -point numerical scale.

\section{Pilot study and data collection}

To test the feasibility and to discover any potential deficiencies, 25 students were included for a pilot study. As there were no issues detected regarding the format or understanding of the questionnaire, all the questions were retained. The process of data collection continued by using the convenience sampling method - widely used in social and tourism research field. It adresses the "sampling procedure used to obtain units or people that are the most conveniently available" (Zikmund 2003). The data was collected over a two months period from October until December. The difficulty in collecting the data was the fact that majority of the survey was supposed to be conducted after forming a group of participants and showing them video. The best option to collect data was to join one of the classes at the Tourism Faculty in Akdeniz University Campus in Antalya. Another way of collecting the data was done by randomly selecting a group of 5-7 participants who were also watching video and filling out the questionnaire under the same conditions, only in the smaller groups. The data collection process was finalized with a total of 227 valid questionnaires collected. The last question in the questionnaire was addressed the question of if the participant knew the name of destination or not. 27 of the 227 participants knew that Vancouver or Canada was the destination shown in the video. Because of this reason, as the assumption of unfamiliarity was broken, these 27 questionnaires were excluded from the analysis. Thus, 200 of the questionnaires were used for the data analysis.

\section{Data analysis}

The SPSS program was used to perform the necessary statistical tests and to analyze the data in several stages. Initially the possible errors in data set, as well as validity and normality tests were conducted, followed by reporting on descriptive statistics. Next, exploratory factor analysis was used to derive fundamental personality dimension of Destination Z, which was shown in research video. After Cronbach's alpha values showed the reliability of the scale, factor scores for the identified dimensions were calculated according to Anderson and Rubin method. Cronbach's alpha coefficients were also checked for the self-congruity measures; by calculating their mean scores, six measures of two dimensions of self-congruity theory were reduced to actual and ideal congruity. At the end of the data analysis process, the relationships between destination personality, self-congruity, and visiting intentions were examined by means of multiple regression analyses.

\section{Results}

After analyzing the descriptive statistics of the 200 participants included in this study, it was found there was an almost equal number of male and female participants: 101 females (50.5\%) and 99 males (49.5\%). The age of the respondents ranged from 18 - 35 with the percentage scores as follows: the group up to the age of $23-42.5 \%$; $45.5 \%$ were in the age range 24-29, and the rest of respondents were aged from 30 - 35 years old, $12 \%$ of the total number of participants. This was considered a good sample of participants as this population spends respectively more time on the Internet and the chance they may end up finding the video of this destination during their search of the Web is larger than for older aged groups. In 
this context, the results of research for this age group may be good to see the effects of tourism promotional videos on the population under the age of 35.

In the first stage, exploratory factor analysis was conducted on the 26 personality items to define the a priori dimensionality of the destination personality scale. First principal component analysis and latent root criterion (eigenvalues $>1$ ) helped in extracting the underlying factors. At this point 7 factors showed eigenvalues larger than 1 . However their total explained variance was low considering the higher number of factors. Therefore to reduce them to a statistically more significant size, the Scree plot was also examined. The curve started to show an almost straight line after the fourth dimension, so it was decided to extract 4 factors in total. The orthogonal (Varimax) rotation method was used, as suggested by Hair (1998), to define theoretically meaningful structures and also because this approach employs the same rotation technique as in previous studies (Aaker 1997; Ekinci et al 2006; Usakli \& Baloglu 2011) which facilitates comparison. According to Hair's et al. (1998) guidelines for a sample size of 200, the criterion of 0.40 was used for the significance of the factor loadings. In the process of factor extracting, those factors showing loadings lower than 0.40 or cross loadings were removed from the analysis. Eight items were deleted upon inspection of the item content for domain representation. All items showed factor loadings higher than 0.40, with no item being cross-loaded.

The results of Bartlett's Test of Sphericity ( $\rho=.000$, chi square: 1148.622, df: 153 ) and Kaiser-Meter-Olkin (KMO) test (.810), both being at significant level, demonstrated the "factorability of the matrices being considered" (Hair et al. 1998). The results of conducting factor analysis determined 4 factor solutions which explained 55, 34\% of the variance. For the reliability test, Cronbach's alpha showed satisfactory values ranging from 0.641 to 0.761 . The results of exploratory factor analysis are shown in Table 1. Title was given for every factor based on factor loadings, the nature of the item in each factor, as well as comparing the fivefactor solution obtained in previous studies (Aaker 1997; Usakli \& Baloglu 2011) and the three-factor solution (Ekinci et al. 2006). This study revealed that the brand personality of the destination used in this case has four dimensions, which is different when looking at three of the five factors found in the studies mentioned above. This is consistent with Hosany's statement (Hosany et al. 2007) that some of the items of Aaker's BPS are not applicable to tourism destinations and that they may differ from destination to destination.

As one of the superior and unbiased methods to calculate factor's scores, Anderson and Rubin methods were chosen. (Sirakaya, Uysal \& Yoshioka 2003). In the work of Sirakaya et al. (2003) it was also stated that Anderson and Rubin method is the standard practice when factors are used as an input for following analyses (multiple regression analyses in this case). 
Table 1. EFA for destination personality items ${ }^{1}$

\begin{tabular}{|c|c|c|c|c|}
\hline Factor & $\begin{array}{c}\text { Factor } \\
\text { loadings }\end{array}$ & Eigenvalue & $\begin{array}{c}\text { Explained } \\
\text { variance (\%) }\end{array}$ & Reliability \\
\hline Competence & & 5.222 & 14.513 & .761 \\
\hline Successful & .750 & & & \\
\hline Technical & .709 & & & \\
\hline Intelligent & 625 & & & \\
\hline $\begin{array}{l}\text { Smooth } \\
\text { Confident }\end{array}$ & $\begin{array}{l}.606 \\
.578\end{array}$ & & & \\
\hline Contemporary & & 1.763 & 14.163 & .695 \\
\hline Up-to-date & 698 & & & \\
\hline Glamorous & 626 & & & \\
\hline Rugged & 625 & & & \\
\hline Modern & 605 & & & \\
\hline Contemporary & .561 & & & \\
\hline Sophisticated & & 1.681 & 14.159 & .707 \\
\hline $\begin{array}{l}\text { Charming } \\
\text { Good looking }\end{array}$ & $\begin{array}{l}.794 \\
.654\end{array}$ & & & \\
\hline Cool & 636 & & & \\
\hline Outdoorsy & 481 & & & \\
\hline $\begin{array}{l}\text { Excitement } \\
\text { Unique }\end{array}$ & .765 & 1.295 & 12.504 & 641 \\
\hline Daring & 680 & & & \\
\hline Exciting & 605 & & & \\
\hline Cheerful & .436 & & & \\
\hline Total explained variance & & & 55.340 & \\
\hline
\end{tabular}

${ }^{1}$ Extraction method: principal component analysis; rotation method: varimax; KMO: 810. Bartlett's Test of Sphericity $\rho$ value .000, chi square: 1148.622, df: 153.

The levels of agreement of the participants' responses to the six self-congruity statements were evaluated. The reliability scores were computed for these measures, but before this the factor structure was tested.

Bartlett's Test of Sphericity's ( $\rho=.000$, chi square: 369.174, df: 15) and Kaiser-Meter-Olkin (KMO) test's (.711) results, demonstrated the factorability of the matrices being considered (Hair et al. 1998). The factor analysis approved the two factor solution found in the literature, which explained $68,52 \%$ of the total variance. Both actual and ideal self-congruity demonstrated significant internal consistency shown by Cronbach's alpha value of 0.735 for actual and of 0.785 for ideal self-congruity (as shown in Table 2). These finding were also consistent with Usakli and Baloglu (2011), and the same as in their research, the six measures of self-congruity were reduced to two variables, as actual and ideal congruity, by computing their means scores which are used in the multiple regression analysis. 
Table 2. Reliability scores for the self -congruity scale ( $\mathrm{N}=200)$

\begin{tabular}{lll}
\hline $\begin{array}{l}\text { Dimensions of self- } \\
\text { congruity theory }\end{array}$ & Reliability & Number of items \\
\hline Actual self-congruity & .735 & 3 \\
Ideal self-congruity & .785 & 3
\end{tabular}

Regression analysis was conducted to test the hypothesis concerning the connection between the destination brand personality and visiting intentions towards that destination (Table 3). A regression analyses was run using four factors as independent variables and visiting intentions as a dependent one, as shown in the table below and, as it can be concluded that destination personality dimensions are able to estimate intention to visit one destination significantly ( $\rho$ $=.000)$

In our first regression model the coefficient of determination $\left(\mathrm{R}^{2}\right)$ was .172 indicating that a little more than $17 \%$ of the total variation in intention to visit is explained by the destination personality factors. There was no effect of multicollinearity due to the fact that the VIF score was 1.000 .

Three dimensions of BPS scale, Competence $(\beta=.171 \rho=.009)$, Sophistication $(\beta=.278 \rho=.000)$ and Excitement $(\beta=.244 \rho=.000)$ had a significant and positive impact on intention to visit the destination. Contemporary ( $\beta=.080 \rho=.223$ ) factor did not have a significant impact on visiting intentions. According to regression analysis, brand personality scale has a positive effect on the intention to visit one destination; therefore the Hypothesis 1 was supported.

Table 3. Regression analysis: the relationship between destination personality and visiting intentions

\begin{tabular}{lllc}
\hline Dimension & \multicolumn{3}{l}{ Intention to visit } \\
\hline & Beta & t-Value & Sig.t \\
\hline Competence & .171 & 2.621 & .009 \\
Contemporary & .080 & 1.222 & .223 \\
Sophistication & .278 & 4.271 & .000 \\
Excitement & .244 & 3.740 & .000 \\
Constant & & 100.245 & .000 \\
Multiple R & .415 & & \\
$\mathbf{R}^{2}$ & .172 & & \\
F test statistics/ & & $\mathrm{F}=10.150$ & \\
significance & & $\rho=.000$ &
\end{tabular}

Visiting intentions were regressed on two measures of self-congruity (Table 4). The two measures explained only $13,6 \%$ of the variation in intention to visit. As the model is statistically significant at .000 it can be concluded that there was a significant relationship between self-congruity and visiting intentions. By calculating the VIFs, multicollinearity between the independent variables was examined. All of the VIF scores were 1.268 and therefore no effect of muticollinearity was detected.

While actual self-congruity was found not to be a significant predictor of visiting intentions 
( $\beta=.130 \rho=.083)$, the opposite was found for the ideal self-congruity dimension $(\beta=.290$ $\rho=.000$ ). This was partially consistent with the results of previous research where both dimensions were found to be significant predictors (Sirgy \& Su 2000; Usakli \& Baloglu 2011). Therefore, according to the overall significance of the regression model, it can be conclude that Hypothesis 2 and $2 \mathrm{~b}$ were supported, while the Hypothesis 2a was rejected.

Table 4. Regression analysis: the relationship between self-congruity and behavioural intention

\begin{tabular}{lccc}
\hline Dimension & \multicolumn{3}{l}{ Intention to visit } \\
\hline & Beta & t-Value & Sig.t \\
\hline Actual congruity & .130 & 1.742 & .083 \\
Ideal congruity & .290 & 3.889 & .000 \\
Constant & & 8.907 & .000 \\
Multiple R & .368 & & \\
$\mathbf{R}^{2}$ & .136 & & \\
F test statistics/ & & $\mathrm{F}=15.470$ & \\
significance & & $\rho=.000$ & \\
\hline
\end{tabular}

In order to test the mediating impact of self-congruity on the relationship between destination personality and destination visiting intentions, Baron and Kenny's (1986) approach was used. The four steps of this approach and the regression analyses results are presented in the continuation.

"Step 1: Regressing the dependent variable on the independent variable, where the independent variable must affect the dependent one".

Tourist behavioural intention were regressed on all dimensions of destination personality and the statistically significant effect of these on visiting intentions was found $(\rho=.000)$ as shown in Table 3. This supports the statement of the first step because there is a basis to claim that this relationship might be mediated by another variable.

"Step 2: Regressing the mediator on the independent variable, where the independent variable must affect the mediator".

Following indications in the second step both dimensions of self-congruity were regressed in all four dimensions of destination personality (table 5).

The two models examined were significant at .000 indicating that there was a meaningful relationship between destination personality and self-congruity. This is consistent with the findings of Murphy et. al. (2007) and Usakli \& Balouglu (2011). The four dimensions of destination personality respectively explained $22.4 \%$ and $20.3 \%$ of the total variation in actual and ideal self-congruity. Competence, sophistication and excitement factors were significant in predicting both actual self-congruity $(\rho=.000, \rho=.000, \rho=.001$ respectively) and ideal selfcongruity ( $\rho=.000, \rho=.000, \rho=.006$ respectively). Due to the overall significance of the regression model at .000 , the second step of the suggested multiple regression approach can be considered completed in terms that the independent variable has an effect on the mediator. 
Table 5. Regression analysis: the relationship between destination personality and selfcongruity

\begin{tabular}{|c|c|c|c|c|c|c|}
\hline \multirow[t]{2}{*}{ Dimension } & \multicolumn{3}{|c|}{ Model 1 Actual congruity } & \multicolumn{3}{|c|}{ Model 2 Ideal congruity } \\
\hline & Beta & t-Value & Sig t. & Beta & $\therefore$-Value & Sig t. \\
\hline Competence & .296 & 4.697 & .000 & .201 & 3.138 & .000 \\
\hline Contemporary & .011 & .179 & .858 & -.031 & -.487 & .627 \\
\hline Sophistication & .300 & 4.760 & .000 & .361 & 5.649 & .000 \\
\hline Excitement & .214 & 3.391 & .001 & .176 & 2.751 & .006 \\
\hline Constant & & 95.412 & .000 & & 89.198 & .000 \\
\hline Multiple R & .473 & & & .450 & & \\
\hline $\mathbf{R}^{2}$ & .224 & & & .203 & & \\
\hline $\begin{array}{l}\text { F test } \\
\text { statistics/ } \\
\text { significance }\end{array}$ & & $\begin{array}{l}F=14.06 \\
\rho=.000\end{array}$ & & & $\begin{array}{l}F=12.3 \mathrm{~s} \\
\rho=.000\end{array}$ & \\
\hline
\end{tabular}

"Step 3: Regressing the dependent variable on both the independent variable and the mediator where the mediator must affect the dependent variable".

In this phase the intention to visit destination was regressed on all dimensions of the destination personality and measures of self-congruity (Table 6). This model was statistically significant in estimating the intention to visit $(\rho=.000)$. In this model the coefficient of determination $\left(\mathrm{R}^{2}\right)$ was .211 showing that $21.1 \%$ of the total variance in the estimation of intention to visit was explained by both the dimensions of destination personality and two self-congruity measures. Again the multicollinearity issue was examined by using VIFs. Their values ranging from 1.002 to 1.439 indicated there was no problem with multicollinearity.

Table 6. Regression analysis: The relationship between destination personality, self-congruity, and intention to visit

\begin{tabular}{lccc}
\hline \multicolumn{3}{l}{ Intention to visit } \\
\hline IVs and mediator & Beta & $\mathrm{t}$-Value & Sig.t \\
\hline Competence & .120 & 1.767 & .079 \\
Contemporary & .086 & 1.341 & .181 \\
Sophistication & .194 & 2.751 & .007 \\
Excitement & .201 & 3.026 & .003 \\
Actual congruity & .029 & .382 & .703 \\
Ideal congruity & .210 & 2.772 & .006 \\
Constant & & 9.845 & .000 \\
Multiple R & .460 & & \\
$\mathbf{R}^{2}$ & .211 & & \\
F test statistics/ & & $\mathrm{F}=8.613$ & \\
significance & & $\rho=.000$ & \\
\hline
\end{tabular}


According to Baron and Kenny (1986), the third step requires that the mediator affects the tourist's behaviour or, in case of this research, self-congruity must have effect on the intention to visit. Results from table 6 show that not both dimensions of self-congruity have a statistically significant affect on the intention to visit. The regression coefficient representing the effect of ideal self-congruity on visiting intentions was significant at $\rho=.006$ while the same cannot be said for the effect of actual self-congruity with $\rho=.703$ which cannot be considered as statistically significant. These results are different from those obtained by Usakli and Baloglu (2011) whose study showed that both dimensions of self-congruity have a statistically significant effect on tourist behavioural intention. However, the regression model being statistically significant at $\rho=.000$, we can conclude that the third step is also satisfied.

"Step 4: If all the conditions from three above mentioned steps are met in the predicted direction, then the effect of the independent variable on the dependent variable must be less in the third step than in the first one".

The final phase of Baron and Kenny's (1986) requires that the regression coefficients representing the independent variable's effects on the dependent variable, should be lower in magnitude in the regression equations that included the mediator than the regression equation that excluded the mediator. Comparison of the regression coefficients and the $\rho$ values (presented in tables 3 and 6) are presented through Step 1 and Step 3 in Table 7.

Table 7. A comparison of regression coefficients and $\rho$ values for destination personality dimensions between step 1 and step 3

\begin{tabular}{|c|c|c|c|c|}
\hline \multirow{3}{*}{ Dimension } & \multicolumn{4}{|c|}{ Intention to visit } \\
\hline & \multicolumn{2}{|l|}{ Step 1} & \multicolumn{2}{|c|}{ Step 3} \\
\hline & Beta & Sig.t & Beta & Sig.t \\
\hline Competence & .171 & .009 & .120 & .079 \\
\hline Contemporary & .080 & .223 & .086 & .181 \\
\hline Sophistication & .278 & .000 & .194 & .007 \\
\hline Excitement & .244 & .000 & .201 & .003 \\
\hline
\end{tabular}

Step 1: regression analyses predicting the behavioural intentions (dependent variable) with destination personality (independent variable). Step 3: regression analyses predicting the behavioural intentions (dependent variable) with destination personality (independent variable) and self-congruity (mediator).

When two of the self-congruity measures were controlled, two destination personality factors (sophistication and excitement) were still significant in predicting visiting intentions towards the destination shown in the video. Comparison of the regression coefficients showed that the effects of almost all dimensions of the destination personality (contemporary dimension only showed a minimum increase of $\beta$ value from $\beta=0.80$ in step 1 to $\beta=.086$ in step 3) on the intention to visit were decreasing when the two self-congruity measures were controlled. Also when comparing the $\mathrm{R}^{2}$ values, it may be seen that in the first step, dimensions of brand personality explained $17.2 \%$ of the total variance in estimation of intention to visit, while in the second step, when the dimension of self-congruity were added, it explained $21.1 \%$ of the total variance in the estimation of visiting intentions. Therefore, it may be concluded that Hypothesis 3 was supported. 
When self-congruity is in a mediator role, all the regression coefficients of the destination personality dimensions are reduced. However, as some of these coefficients are still significant, it may be concluded that self-congruity represents a partial mediator between destination personality and visiting intentions.

\section{Conclusion}

The goal of this research was to examine the relationship between the perceived destination personality of a destination unknown to the participants of the research, dimensions of selfcongruity theory and tourist behaviour intentions in terms of visiting this destination. After analyzing the data, it was founded that the brand personality of destination used in this research has 4 dimensions which are named in the same way as those of Aaker (1997) and (Usakli \& Baloglu 2011) but containing different personality traits in some of the dimensions. The transition of personality traits from one dimension to another may also be seen in previous studies (e.g. Ekinci \& Hosany 2006, Murphy 2007; Usakli \& Baloglu 2011). As suggested by Ekinci and Hosany (2006) this is because personality traits designed by Aaker (1997) "for consumer goods tend to shift when applied to tourism destinations".

The results of this study indicate that the perceived destination personality of an unknown destination has positive impact on visiting intentions for that destination. This paper is also a significant theoretical contribution as these findings support the self-congruity theory in terms of compatibility between the destination personality and the tourist's concept of self, consistent with the findings of Usakli and Baloglu (2011). Another goal of this research was, at a certain point, to fill the gap in research on self-congruity theory in tourism studies.

The findings of this research provide at least three important implications for destination marketers. The high competition between all destinations in the world, product similarity and growing substitutability has resulted in tourists becoming immune to promotion solely on a destinations' functional attribute, as they are not able to help in attracting the potential tourist, which was the case in the past. In order to understand the complexity of tourist behaviour, it is necessary to deal with the symbolic functions of the destination brand. As this study shows that destination personality positively influences tourist behavioural intentions, it is a good sign for destination marketers to focus upon developing marketing strategies that underline the unique personality of their destinations.

The second implication is in regard to the necessity for marketers to place a greater stress upon "creating a bridge" between the destination personality and the tourist's self-concept. The findings of this study show that tourists who can match the way they perceive one destination with how they see, or would like to see themselves, are more likely to react positively towards that destination, resulting in the desire to visit the destination. Tourism marketers should consider developing campaigns that emphasize this match.

The findings of this study, as well as the method in which research was conducted, can be used to examine whether the already planned marketing strategies and activities related to promotional tourism videos are providing the desired results. It can be used by tourism marketers to test if the message and impression they wanted to send to the potential visitor of their destinations are perceived in the correct manner and to what extent are they compatible with the visitor him/her-self.

Some important limitations of this study should be taken into consideration. The convenience sampling method, as well as size of the sample and the age group tested, did not reflect the entire population that the research should be conducted on. Additionally, the findings 
of this study are specific to only the investigated destination (Vancouver, Canada) and broader generalizations cannot be made. Accordingly, in future studies a larger sample size should be used and the design of this research should be replicated with other destinations. In this way a broader understanding of this research area may be obtained. 


\section{REFERENCES}

Aaker J. L. (1995). Brand Personality: Conceptualization, Measurement and Underlying Psychological Mechanism. (Unpublished Doctoral Dissertation). Stanford University, Stanford, CA 1995.

Aaker J. L. (1997). "Dimensions of Brand Personality”. Journal of Marketing Research, 34 (1997) 347-356.

Baron R. M. \& Kenny D. A. (1986). "The Moderator - Mediator Variable Distinction in Social Psychological Research: Conceptual, Strategic, and Statistical Considerations". Journal of Personality and Social Psychology 51/6 (1986) 1173-1182.

Belk R. W. (1988). "Possesions and the Extended Self”. Journal of the Consumer Research 2 (1988) 139-168.

Chen C. F. \& Tsai D. (2007). "How Destination Image and Evaluative Factors Affect Behavioural Intentions?”. Tourism Management 28 (2007) 1115-1122.

Ekinci Y. \& Hosany S. (2006). "Destination Personality: An Application of Brand Personality to Tourism Destinations”. Journal of Travel Research. 45 (2006) 127-139.

Ekinci Y., Sirakaya-Turk E. \& Baloglu S. (2007). "Host Image and Destination Personality”. Tourism Analysis 12 (2007) 433-446.

Hair Jr. J. F, Anderson R. E, Tatham R. L. \& Black W. C. (1998). Multivariate Data Analysis. New Jersey 1998.

Helgeson J. G. \& Suphellen M. (2004). “A Conceptual and Measurement Comparison of Self-Congruity and Brand Personality”. International Journal of Market Research 46 /2 (2004) 205-233.

Hosany S., Ekinci Y. \& Uysal M. (2006). "Destination Image and Destination Personality: An Application of Branding Theories to Tourism Places”. Journal of Business Research 59 (2006) 638-642.

Keller K. L. (1993). "Conceptualising, Measuring and Managing Customer-Based Brand Equity”. Journal of Marketing 57 (1993) 1-22.

Kleine R.E., Kleine S. S. \& Kernan J. B. (1993). "Mundane Consumption and the Self: Social-Identity Perspective”. Journal of Consumer Psychology 2/3 (1993) 209-235.

Levy S. J. (1955).”Symbols for Sales”. Harvard Business Review 37/4 (1955) 117-124.

Malhotra N. K. (1988). "Self-Concept and Product Choice: An Integrated Perspective". Journal of Economic Psychology 9 (1988) 1-28.

Nicoletta R. \& Servidio R. (2012). “Tourists’ Opinion and Their Selection of Tourism Destination Images: An Affective and Motivational Evaluation”. Tourism Management Perspectives 4 (2012) 19-27.

Park B. (1986). “A Method for Studying the Development of Impressions of Real People”. Journal of Personality and Social Psychology 51 (1986) 907-917.

Plummer J. T. (1985). "How Personality Makes a Difference”. Journal of Advertising Research 24/6 (1985) 27-31.

Rosenberg M. (1979). Conceiving the Self. New York, Basic Books 1979.

Siry M. J. (1982). "Self-Concept in Consumer Behaviour: A Critical Review”. Journal of Consumer Research 9 (1982) 287-300.

Sirgy M. J., Grewal D. Mangleburg T. F., Park J., Chon K. \& Claiborne C. B. (1997). "Assessing the Predictive Validity of Two Methods of Measuring Self-Image Congruence”. Journal of the Academy of Marketing Science 25/3 (1997) 229-241.

Sirgy M. J. \& Su C. (2000). "Destination Image, Self-Congruity, and Travel Behaviour: Toward an Integrative Model”. Journal of Travel Research 38 (2000) 340-352.

Tasci, A. D. A. \& Kozak M. (2006). Destination Brands vs Destination Images: Do We Know What We Mean? Journal of Vacation Marketing J2/4 (2006) 299-317.

Usakli A. \& Baloglu S. (2011) "Brand Personality of Tourist Destinations: An Application of SelfCongruity Theory". Tourism Management 32 (2011)114-127.

Yüksel A. \& Akgül O. (2007). "Postcards as Affective Image Makers: An Idle Agent in Destination Marketing”. Tourism Management 28 (2007) 714-725.

Zikmund W.G. (20037). Business Research Methods. Mason, OH 2003. 